\section{Extension of Muskmelon Storage Life through the Use of Hot Water Treatment and Polyethylene Wraps}

\author{
K.S. Mayberry and T.K. Hartz \\ University of California Cooperative Extension, 1050 E. Holton Rd., \\ Holtville, CA 92250
}

Additional index words. Cucumis melo, postharvest, fruit quality, firmness, decay

Abstract. Trials were conducted in California to evaluate techniques to extend storage life of netted muskmelons (Cucumis melo $\mathbf{L}$.). The use of polyethylene bags, either as individual melon wraps or as liners for 18 -kg commercial cartons, minimized water loss and associated deterioration of the fruit. Individual bags and carton liners were equally effective. A 3-minute dip in $60 \mathrm{C}$ water effectively checked surface mold development on wrapped fruits. Lower temperature and/or shorter exposure treatments were less effective. When applied in addition to hot water treatment, imazalil fungicide did not confer significant additional benefit. The combination of polyethylene bags and hot water treatment maintained high quality, marketable fruit for at least 28 days of storage at $3 \mathrm{C}$,

Muskmelon fruit have a relatively short storage life. Under current commercial handling techniques substantial loss of marketability commonly occurs within 2 weeks of harvest (Ryan and Lipton, 1979). This limitation severely limits the possibility of exporting U.S.-grown muskmelons to potentially lucrative markets in Europe and the Far East, since ocean transport to these destinations can take up to 3 weeks. Fungal rots are a factor in postharvest deterioration of muskmelon. Several studies have demonstrated the efficacy of hot-water and fungicide treatments in controlling stem scar and surface fungal growth (Carter, 1981a; McDonald and Buford, 1971; Stewart and Wells, 1970). The other major factor limiting muskmelon storage life is desiccation. Lester and Bruton (1986) showed that fruit maintained at 4C and $85 \%$ to $95 \%$ relative humidity (typical of commercial storage conditions) lost 5.7\% in fresh weight within 20 days, with concomitant decreases in firmness, dry weight, and soluble sugars, and loss of membrane integrity. Equivalent storage of fruits that had been shrink film-wrapped to maintain a saturated microatmosphere lost only $0.6 \%$ of fresh weight in 30 days, with no significant loss in other characteristics noted. They considered $87 \%$ of shrink-wrapped melons to be of good appearance (marketability) after 30 days of storage.

The applicability of shrink-wrap technology to commercial muskmelon marketing is limited by several factors. Costly, highly specialized machinery is required; the slow speed of operation may also create a bottle-

Received for publication 14 Jan. 1991. Accepted for publication 20 Sept. 1991. The cost of publishing this paper was defrayed in part by the payment of page charges. Under postal regulations, this paper therefore must be hereby marked advertisement solely to indicate this fact.

'Dept. of Vegetable Crops, Univ. of California, Davis, CA 95616. neck in packing-shed operations. Further, serious decay problems can be encountered when shrink-wrapped muskmelons are removed from long-term cold storage and kept at room temperature (T. K. H., unpublished data), as is normally done at the retail marketplace. The use of polyethylene bags, either as an individual fruit wrap or a liner for conventional $18-\mathrm{kg}$ commercial cartons, would provide a barrier to fruit desiccation and would meet these limitations of shrink-wrapping. Our objective was to test the efficacy of polyethylene wrapping, in conjunction with decay control measures, in extending storage life of muskmelon.

High quality netted muskmelons ('Topmark') were selected from a commercial packinghouse in El Centro, Calif., on 12 Nov. 1987. The fruit were separated into groups of similar size and appearance. Postharvest treatment consisted of various combinations of heat, fungicide application, and polyeth-

Table 1. Effects of polyethylene wrapping and decay control techniques on muskmelon quality after 40 days of storage at 3C, 1987 test.

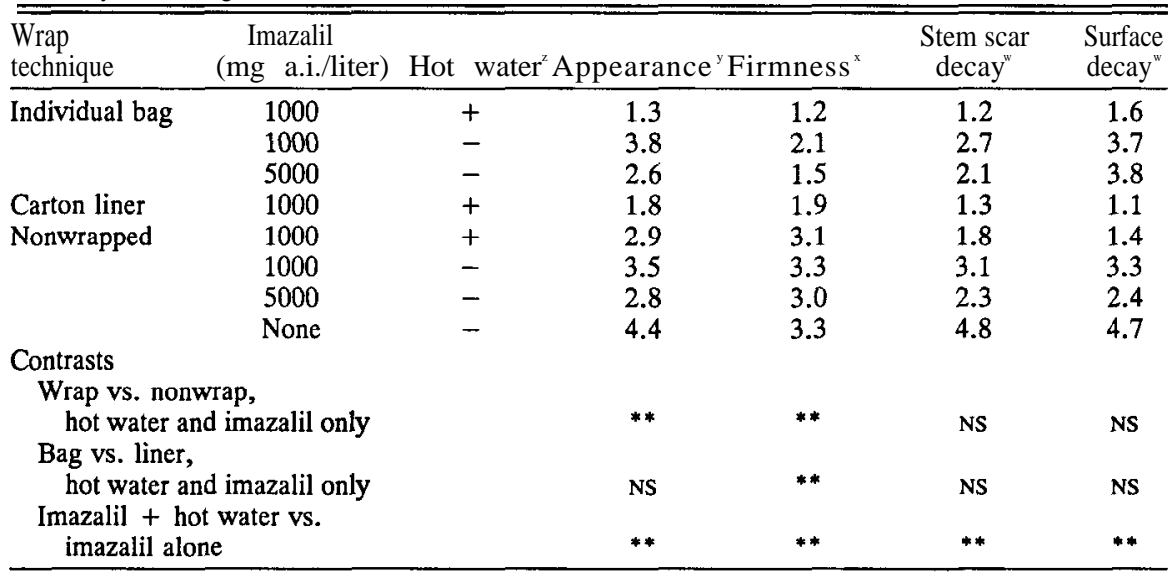

Three-min exposure at $60 \mathrm{C} ;+=$ yes, $-=$ no.

$y_{1}=$ excellent, $5=$ unmarketable.

${ }^{x} 1=$ hard, $5=$ unmarketably soft.

${ }^{\mathrm{w}} 1=$ none, $5=$ severe mold growth

**,NsSignificant at $P=0.01$ or not significant, respectively. 
Table 2. Effects of polyethylene wrapping and decay control techniques on muskmelon quality after 28 days of storage at $3 \mathrm{C}, 1989$ test.

\begin{tabular}{|c|c|c|c|c|c|c|}
\hline $\begin{array}{l}\text { Wrap } \\
\text { technique }\end{array}$ & Imazalil $^{\mathbf{z}}$ & Hot watery & Appearance $^{x}$ & $\begin{array}{c}\text { Firm- } \\
\text { ness }\end{array}$ & $\begin{array}{c}\text { Stem scar } \\
\text { decay }^{*}\end{array}$ & $\begin{array}{l}\text { Surface } \\
\text { decay }^{v}\end{array}$ \\
\hline \multirow[t]{3}{*}{ Individual bag } & - & + & $1.0(2.4)^{\mathrm{u}}$ & $1.3(3.1)$ & $1.0(1.0)$ & $\begin{array}{l}1.0 \\
(2.1)\end{array}$ \\
\hline & + & + & $1.0(1.6)$ & $1.3(2.1)$ & $1.0(1.0)$ & $\begin{array}{l}1.0 \\
(1.0)\end{array}$ \\
\hline & - & - & $5.0(5.0)$ & $3.3(5.0)$ & $5.0(5.0)$ & $\begin{array}{c}5.0 \\
(5.0)\end{array}$ \\
\hline \multirow[t]{2}{*}{ Carton liner } & - & + & $1.0(2.1)$ & $1.4(2.1)$ & $1.0(1.0)$ & $\begin{array}{l}1.0 \\
(1.0)\end{array}$ \\
\hline & + & + & $1.0(2.5)$ & $1.6(3.0)$ & $1.0(1.0)$ & $\begin{array}{l}1.0 \\
(1.1)\end{array}$ \\
\hline \multirow[t]{2}{*}{ Nonwrapped } & + & + & $2.9(3.6)$ & $3.3(3.8)$ & $1.3(1.0)$ & $\begin{array}{l}1.6 \\
(2.0)\end{array}$ \\
\hline & - & - & $3.9(5.0)$ & $3.3(4.4)$ & $4.9(5.0)$ & $\begin{array}{l}3.5 \\
(4.8)\end{array}$ \\
\hline \multicolumn{7}{|c|}{ Contrasts } \\
\hline $\begin{array}{l}\text { Wrap vs. no } \\
\text { hot water } \\
\text { Indiv. bag v }\end{array}$ & $\begin{array}{l}\text { mazalil only } \\
\text { aer, }\end{array}$ & & $* *(* *)$ & $* *(* *)$ & NS (NS) & $* *(* *)$ \\
\hline \multicolumn{7}{|c|}{ Hot water alone vs. } \\
\hline hot water & mazalil & & NS (NS) & NS (NS) & NS (NS) & NS (NS) \\
\hline
\end{tabular}

$2000 \mathrm{mg}$ a.i./litcr; $+=$ ycs, $=$ no.

Three-min exposure at $60 \mathrm{C} ;+=$ yes, $-=$ no.

$x_{1}=$ excellent, $5=$ unmarketable.

${ }^{*} \mathbf{1}=$ hard, 5 = unmarketably soft.

$\mathrm{v}_{1}=$ none, $5=$ severe mold growth.

"( ) indicates rating after 2 days of additional storage at $25 \mathrm{C}$.

**,NSSignificant at $P=0.01$ or not significant, respectively.

Table 3. Effects of hot water treatments on muskmelon quality after 28 days of storage at 3C, 1990 test.

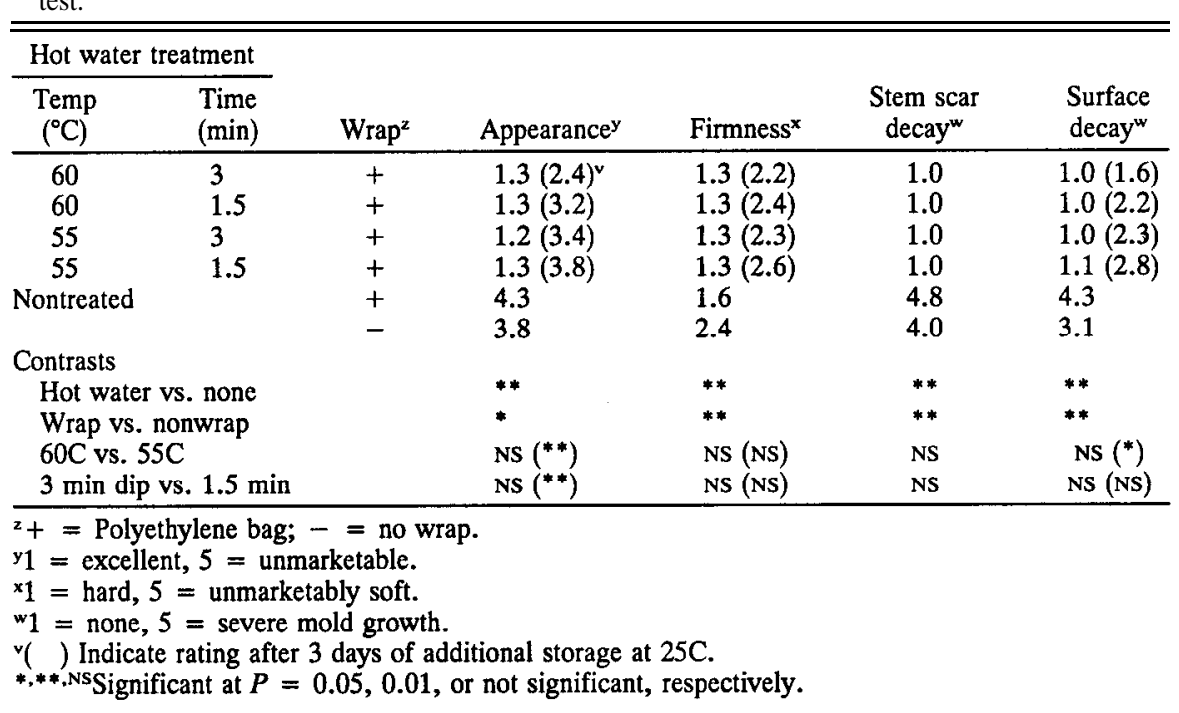

a less severe heat treatment would be effective in controlling mold development on wrapped melons. 'Topmark' muskmelons were harvested on 6 June. After separation into equal groups, hot water dips of 60 or $55 \mathrm{C}$ at duration of 1.5 or $3.0 \mathrm{~min}$ were imposed. Fruit were then placed in individual bags and stored at $3 \mathrm{C}$. The fruit were removed from cold storage after 4 weeks and evaluated. All specimens were removed from the bags and kept at $25 \mathrm{C}$ for 3 days to simulate retail display, then reevaluated.

In 1987 the combination of hot water dip, $1000 \mathrm{mg}$ imazalil/liter, and wrapping (either individually or by carton liner) allowed the maintenance of high quality muskmelon through 40 days of storage (Table 1). Neither these fruit. There were no significant differences between fruit wrapped in individual bags and those stored within carton liners. Again, both wrapping methods maintained fruit firmness. Wrapping untreated melons resulted in rampant growth of stem-scar and surface decay organisms, rendering all fruits unmarketable. Heat treatment and fungicide application minimized decay development on unwrapped fruit, but firmness and appearance of these melons was at the lower limit of acceptability.

Melons in all treatments showed relatively rapid degradation of firmness and appearance after only 2 days of additional storage at $25 \mathrm{C}$, particularly heat-treated, wrapped fruits. Some of these melons showed surface browning that detracted from overall appearance.

All dip temperature/time exposure combinations were equally effective in improving fruit quality of wrapped melons during 28 days of cold storage (Table 3 ). Heattreated, wrapped fruit were of good quality, essentially free from decay. After 3 days of subsequent storage at $25 \mathrm{C}$ differences due to heat-treatment effects were noted. Water at $60 \mathrm{C}$ was superior to $55 \mathrm{C}$ with respect to appearance and surface decay; appearance was also significantly better with the 3-rein than the 1.5-rein dip. The surface discoloration noted in 1989 was not appreciable in any treatment in 1990.

When combined with hot water treatment, polyethylene wraps maintained muskmelon fruit quality through at least 28 days of conventional cold storage. A major effect of the wrap is minimization of water loss (Lester and Bruton, 1986; Lester et al., 1988; Teitel et al., 1989), as evidenced by the maintenance of fruit firmness in wrapped fruit, while significant softening was observed in nonwrapped melons. Postharvest water loss in muskmelon is relatively rapid; Lester and Bruton (1986) reported an 8.1\% loss in fresh weight after 30 days of high humidity storage. Water loss is particularly rapid where the surface netted tissue is abraded during harvest and packing operations, which results in sunken, discolored areas that significantly detract from appearance. Such sunken areas were readily observable in nonwrapped fruits in our studies. Since nonperforated wraps were used, the atmosphere surrounding the fruit was undoubtedly modified with respect to $\mathrm{CO}_{2}$ and $\mathrm{O}_{2}$ concentration, which may have also influenced the degree of softening and other quality aspects; however, flavor was not evaluated.

Decay control measures were essential for wrapped fruit. In all experiments hot water treatment was highly effective in minimizing the development of surface decay. The imazalil treatment conferred no additional benefit. These results agree with those of Stewart and Wells (1970) but contradict reports by Carter (1981a, 1981b). This discrepancy may in part be related to environmental conditions of the growing areas. Carter worked in south Texas, an area of high humidity and sporadic heavy rain, where losses to rind decay are generally more significant than in the 
arid muskmelon production areas of California, where the present studies and those of Stewart and Wells were conducted. One should not infer that hot water treatment alone would provide acceptable decay control in a commercial packing situation. In these studies, the fruit were carefully screened to provide only the highest quality fruit. Treatments were applied under carefully controlled conditions that would limit recontamination of fruit after the hot water dip. Commercialscale packing operations, particularly in areas prone to high incidence of muskmelon fruit rots, may see substantial benefit with the application of an effective fungicide in addition to hot water treatment. However, increasingly restrictive governmental registration and review procedures severely limit the choice of effective postharvest fungicides; the issue is complicated further for export shipments, since pesticide regulations differ widely among countries.

Hot water treatment is not without problems, however. Both Carter (1981a) and Stewart and Wells (1970) found surface browning, particularly of the vein tracts, to be increased by hot water dips, with the severity of browning increasing with increased exposure time. Teitel et al. (1991) showed that 'Galia' melons were damaged by exposure to $60 \mathrm{C}$ water for as little as $30 \mathrm{sec}$. In the 1989 study, some surface browning was encountered, but it did not significantly compromise marketability. All fruit used in these experiments lacked vein tracts (were fully netted); thus, browning may have been less severe than would have been the case with cultivars that have vein tracts. A $60 \mathrm{C} /$ 3 min treatment may pose a risk under some circumstances. However, reducing temperature and/or exposure time might compromise decay control, as suggested by the 1990 study and by the work of Teitel et al. (1991).

In summary, the use of polyethylene bags, either as an individual fruit wrap or as a liner for $18-\mathrm{kg}$ commercial cartons, minimized softening and extended storage life of muskmelon. Hot water treatment provided adequate control of surface decay organisms. The combination of hot water treatment and polyethylene wrapping allowed maintenance of high quality fruit for at least 28 days of cold storage, sufficient to potentially allow ocean transport of U.S.-grown muskmelons to export markets. However, our procedure cannot be recommended for commercial use until its effects on aroma and flavor have been evaluated.

\section{Literature Cited}

Carter, W.W. 1981a. Postharvest treatment for control of stem-scar, rind and decay fungi on cantaloupe. Plant Dis. 65:815-816.

Carter, W.W. 1981b. Reevaluation of heated water dip as a postharvest treatment for controlling surface and decay fungi of muskmelon fruits. HortScience 16:334-335.

Lester, G.E. and B.D. Bruton. 1986. Relationship of netted muskmelon fruit water loss to postharvest storage life. J. Amer. Soc. Hort. Sci. 111:727-731.

Lester, G., J. Dunlap, and S. Lingle. 1988. Effect of postharvest heating on electrolyte leakage and fresh weight loss from stored muskmelon fruit. HortScience 23:407

McDonald, R.E. and W.R. Buford. 1971. Effect of hot water and fungicides for control of stem scar and rind molds of cantaloupe. Plant Dis. Rptr. 55:183-185.

Ryan, A.L. and W.J. Lipton. 1979. Handling, transportation and storage of fruits and vegetables: vol. 1, 2nd ed. AVI, Westport, Conn. Stewart, J.K. and J.M. Wells. 1970. Heat and fungicide treatments to control decay of cantaloupes. J. Amer. Soc. Hort. Sci. 95:226-229.

Teitel, D. C., R. Barkai-Golan, Y. Aharoni, Z. Copel, and H. Davidson. 1991. Toward a practical postharvest heat treatment for 'Galia' melons. Scientia Hort. 45:339-344.

Teitel, D. C., Y. Aharoni, and R. Barkai-Golan. 1989. The use of heat treatments to extend the shelf life of 'Galia' melons. J. Hort. Sci. 64:367372. 